\title{
C-REACTIVE PROTEIN AND NEUTROPHIL-LYMPHOCYTE RATIO AS PREDICTORS OF CLINICAL SEVERITY OF COVID-19
}

Stefan Pandilov ${ }^{1}$, Suzana Klenkoski ${ }^{1}$, Elena Jovanovska Janeva ${ }^{2}$, Gazmend Mehmeti ${ }^{1}$,Dragan Mijakoski ${ }^{3}$, Sasho Stoleski ${ }^{3}$, Hristian Duma ${ }^{1}$, Dejan Dokic ${ }^{2}$

University Clinic for Eye Diseases; Ss Cyril and Methodius University in Skopje Faculty of Medicine, Republic of North Macedonia.

University Clinic of Pulmonology and Allergy; Ss Cyril and Methodius University in Skopje, Faculty of Medicine, Republic of North Macedonia

Institute of Occupational Health, WHO CC, GA2LEN CC, Skopje; Ss Cyril and Methodius University in Skopje, Faculty of Medicine, Republic of North Macedonia

Citation: Pandilov S, Klenkoski S, Jovanovska Janeva E, Mehmeti G, Mijakoski D, Stoleski S, Duma H, Dokic D. C-reactive protein and Neutrophil-Lymphocyte Ratio as predictors of clinical severity of COVID-19 Arch Pub Health 2021; 13 (2)1-14

doi.org/10.3889/aph.2021.6006

Key words: COVID-19, CRP, NLR, neutrophils,lymphocytes, clinical severity

*Correspondence: Elena Jovanovska Janeva, University Clinic of Pulmonology and Allergy, Skopje, Republic of North Macedonia. E-mail: eli.janeva@ yahoo.com

Received: 17-Aug-2021; Revised: 12-Oct-2021 Accepted: 25-Oct-2021; Published: 12-Nov-2021 Copyright: ${ }^{\circ}$ 2021. Stefan Pandilov, Suzana Klenkoski, Elena Jovanovska Janeva, Gazmend Mehmeti, Dragan Mijakoski, Sasho Stoleski, Hristian Duma, Dejan Dokic. This is an open-access arti cle distributed under the terms of the Creative Commons Attribution License, which permits unrestricted use, distribution, and reproduction in any medium, provided the original author(s) and source are credited.

Competing Interests: The author have declared that no competing interests

\section{Abstract}

COVID-19 is an infectious disease that can manifest quite differently. In this study we examined the relationship between the value of serum CRP(C-reactive protein) andneutrophil-lymphocyte ratio (NLR) as predictor factors for the development of a severe clinical manifestation in COVID19 patients. Materials and methods: We followed 95 COVID-19 positive patients who were hospitalized at the University Clinic for Eye Diseases - COVID Center. We analyzed the initial laboratory parameters of white blood cells and CRP on admission of the patients and the results of laboratory analyses performed before they left the Clinic, or the last parameters before the lethal outcome in those patients who died. Several models of logistic regression were tested to analyze the predictive value of these markers of inflammation for lethal outcome in patients hospitalized for COVID-19. Results: Bivariate analysis demonstrated that the length of hospital stay was significantly shorter in patients with lethal outcome ( $\mathrm{p}=0.001)$. The NLR was significantly higher in patients with lethal outcome at both times $(\mathrm{p}=0.005$; and $\mathrm{p}=0.017)$. Leukocyte's count $(\mathrm{p}=0.046$, and $\mathrm{p}<0.001)$ and CRP $(\mathrm{p}=0.013$,and $\mathrm{p}=0.005)$ were also significantly higher in patients with lethal outcome at both times. The increase on the NLR scale both at hospitalization and at discharge (or the last analysis before death) leads to increase in the odds of lethal outcome (T1:40.4\% increased odds; T2:36\% increased odds). Conclusion: CRP and NLR are laboratory parameters that can predict the severity of the clinical manifestation in patients with COVID-19.

\section{Клинички испитувања}

\section{Ц-РЕАКТИВЕН ПРОТЕИН И СООДНОСОТ НА НЕУТРОФИЛИ- ЛИМФОЦИТИ КАКО ФАКТОРИ ЗА ПРЕДИКТИВНОСТ НА ТЕЖИНАТА НА КЛИНИЧКАТА СЛИКА КАЈ COVID-19}

Стефан Пандилов ${ }^{1}$, Сузана Кленкоски르, Елена Јовановска-Јанева², Газменд Мехмети, Драган Мијакоскиㄱ, Сашо Столески³, Христиан Дума", Дејан Докиќ2

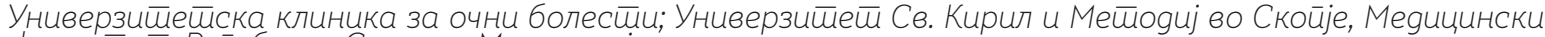
факулиеше, Рейублика Северна Макеgонија

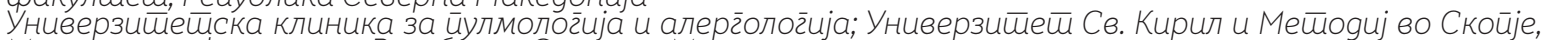
Меgииински факулиетеи, Рейублика Северна; Макеgонија

Инсиййуй за меgицина на йруg на Рейублика Северна Макеgонија, Универзийеӣ Св. Кирил и Мейоgиј во Скойје, Меgицински факулиеш.. Рейублика Северна Макеgонија Цитирање: Пандилов С, Кленкоски С, ЈовановС., Дума Х, Докиќ Д. Ц-реактивен протеин и соодносот на неутрофили-лимфоцити како фактори за предиктивност на тежината на клиничката слика кај COVID-19. Арx J Здравје 2021;13(2) 1-14 doi.org/10.3889/aph.2021.6006 Клучни зборови: COVID-19, CRP, NLR, неутрофили, лимфоцити, тежина на клиничка слика *Кореспонденција: Елена Јовановска-Јанева, Универзитетска клиника за пулмологија и алергологија, Скопје, Република Северна Македонија. E-mail: eli.janeva@yahoo.com

Примено: 17-авг-2021; Ревидирано: 12-окт-2021; Прифатено: 25-окт-2021; Објавено: 12-нов-2021 Печатарски права: 2021 Стефан Пандилов, Сузана Кленкоски, Елена Јовановска-Јанева, Газменд Мехмети, Драган Мијакоски, Сашо Столески, Христиан Дума, Дејан Докик... Ова статија е со отворен пристап дистрибуирана под условите на нелокализирана лиценца, која овоз можува неограничена употреба, дистрибуција и репродукција на било кој медиум, доколку се и репродукција на било кој медиум, доколку се
цитираат оригиналниот(ите) автор(и) и изворот. Конкурентски интереси: Авторот изјавува дека нема конкурентски интереси.

\section{Извадок}

COVID-19 е инфективно заболување кое може да се манифестира доста различно. Во оваа студија ние ја испитувавме поврзаноста помеѓу вредностите на CRP (Ц-реактивен протеин) и соодносот неутрофили-лимфоцити (NLR) како предиктивни фактори за развој на тешка клиничка слика кај пацентите co COVID-19. Материјали и методи:Следевме 95 COVID-19 позитивни пациенти кои беа хоспитализирани во УК за очни болести - COVID центар во Скопје. Ги анализиравме лабораториските параметри на леукоцитите и CRP при прием на пациентите во Клиниката и резултатите од лабораториските анализи изведени пред пациентите да ја напуштат Клиниката или пред нивниот летален исход, кај оние што починаа. Беа тестирани неколку модели на логистичка регресија со цел да се утврди предиктивната вредност на овие маркери на инфламација за летален исход кај пациенти хоспитализирани од COVID-19. Резултати: Анализата покажа дека должината на престој во болница беше значително пократка кај пациентите со летален исход $(=0,001)$. NLR беше значително повисок кај пациенти со летален исход и во двете времиња ( $p=0,005 ;$ и p = 0,017). Бројот на леукоцитите ( $p=0,046$, и $p<0.001)$ и CRP ( $=0,013$, и p =0,005), исто така, беа значително повисоки кај пациенти со летален исход во двете времиња. Повисоки вредности на NLR и при хоспитализација и при отпуштање (или последна анализа пред настапување на смртта) доведува до зголемување на шансите за летален исход (Т1: 40,4\% зголемени шанси; Т2: 36\% зголемени шанси). Заклучок: CRP и NLR се лабораториски параметри кои можат да ја предвидат сериозноста на клиничката слика кај пациенти со COVID-19. 


\section{Introduction}

COVID-19 is a highly infectious disease that has spread throughout the world. The disease is caused by SARS-CoV-2, an RNA virus that has been known to science since 1937 when it was first isolated in chicken embryos. ${ }^{1}$ There is almost no country in the world that has not described at least one case of this disease in the past year. In this way, the disease has affected public health around the world. The clinical picture in patients with COVID-19 is quite different, ranging from asymptomatic to life-threatening. Many patients who initially have mild symptoms, mostly from the upper respiratory tract, develop a severe clinical picture within a few days. So far, it has been shown that patients with a severe clinical picture have a poor chance of survival. The most common causes of death in COVID-19 patients are ARDS, thromboembolic events, acute renal failure, sepsis and septic shock, and acute liver failure. ${ }^{2}$ Therefore, the detection of biological markers in patients who will predict the severity of the clinical picture is crucial to timely indicate appropriate health care. For these reasons, monitoring of vital parameters and laboratory findings have been shown to be predictors of the possibility of developing a severe clinical picture in COVID-19 patients. A few laboratory markers are used as predictors of clinical severity in patients with COVID-19 and for fatal outcome including: CRP (C-reactive protein), the ratio between neutrophils and lymphocytes (NLR), LDH and elevated D-dimer values ${ }^{3,4}$

Serum CRP (C-reactive protein) is known as one of the acute phase proteins. This protein is produced in the liver in response to infection or inflammation. ${ }^{5}$ It starts to increase rapidly in 6-8 hours after the onset of the inflammatory response by the host and reaches maximum values in $48 \mathrm{~h}$ after the onset of inflammation.6 Its half-life is $19^{\text {th }}$, and it begins to decrease as the inflammation subsides and returns to normal values when the body recovers. ${ }^{7}$ Normal values of this laboratory parameter are lower than $6 \mathrm{mg} / \mathrm{l}$. Once created, CRP travels through the bloodstream to the areas of the body where inflammation takes place. It attaches to phosphocholine on the surface of damaged cells and thus activates the classical complement pathway of the immune system, resulting in phagocytosis of damaged cells and bacteria by phagocytic cells. ${ }^{8,9}$

The ratio between neutrophils and lymphocytes (NLR) is another biological marker that can be easily calculated from a standard blood count and can serve as a predictor of the severity of a clinical picture in a variety of conditions. Normal NLR is between 0.78 and 3.53. A value greater than 6 indicates stress in the body..$^{10}$ So far, a lot of data have been published linking NLR as a survival factor in cancer patients, COPD patients and patients with cardiovascular disease. 11-14With the advent of COVID-19, this biomarker (NLR) has been used to assess the possibility of developing a severe clinical picture in patients with COVID-19.15

In this study we examined the relationship between the value of serum CRP and NLR as predictor factors for the development of a severe clinical manifestation in patients with COVID-19.

\section{Material and methods}

For that purpose, in the period from 19.11.2020 to 18.01.2021 we followed 
95 COVID-19 positive patients who were admitted for hospital treatment at the University Clinic for Eye Diseases - COVID Center, at the University Clinic Mother Theresa in Skopje.

Blood samples and laboratory parameters were taken during the hospitalization. In this study, we analyzed the initial laboratory parameters obtained on admission of a patient to our Clinic (T1), and the last laboratory parameters obtained before leaving the Clinic, or the last parameters before the lethal outcome (T2) in those patients who died. Blood was collected $(3 \mathrm{ml})$ in an EDTA-counting tube to determine neutrophil and lymphocyte counts, and a tube without additives to determine CRP as an immune marker. The determination of CRP was performed using turbidimetry. The normal ranges in our laboratory are: for neutrophils 1.2-8.0 x 109 / L (35-80\%), for lymphocytes 0.5$5.0 \times 109$ / L (15-50\%), and for CRP up to $6 \mathrm{mg} / \mathrm{L}$. Normal NLR is between 0.78 and 3.53 .

\section{Statistical analysis}

Independent samples t-test was used to compare data obtained for patients who remained alive and patients with lethal outcome. Several models of logistic regression were tested to analyze the predictive value of white blood cells and CRP, the marker of inflammation, for lethal outcome in patients hospitalized for COVID-19. The models were tested while controlling for age, gender, and length of hospital stay. The factors were entered in a single block and the Enter method was used. The variables related to white blood cells and CRP at both times (T1 and T2) were included in the models. The percentages of neutrophils and lymphocytes were included in each model since they did not demonstrate significant associations with patient outcome within the bivariate analyses and they were used as control variables. However, we tested the predictive value of neutrophils/ lymphocytes ratio, absolute count of leukocytes, and CRP for lethal outcome in this group of patients.

P values $<0.05$ were considered statistically significant, and the main results are given with 95\% confidence intervals (CI). The Statistical Package for the Social Sciences (SPSS) statistics (Chicago USA 2011, version 20) was used for the statistical analyses.

\section{Results}

Out of the total number of patients (95), 56 (59\%) patients were male and the remaining 39 (41\%) were female. The youngest hospitalized patient was 25 years old, and the oldest 87 years. The average age of alivepatients was $60.59 \pm 13.75$ years and the mean of hospital stay in days was $9.68 \pm 4.72$.

In a period of two months, 21 (22\%) of the hospitalized patients died at the Clinic,some of them in the Clinic itself and some in intensive care, after they were transferred due to general health deterioration. Of all those who died, 15 patients were maleand the remaining 6 were female. The average age of the deceased patients was $66.95 \pm 13.9$ years, and the mean of hospital stay in days was $5.33 \pm$ 5.06 .

Bivariate analysis (Table 1) demonstrated that the length of hospital stay was significantly shorter in patients with lethal outcome $(5.33 \pm$ 5.06 vs. $9.68 \pm 4.72, t=-3.662, p=0.001)$. Neutrophils/lymphocytes ratio was significantly higher in patients with lethal outcome at both times (T1: 
$12.05 \pm 7.53$ vs. $6.47 \pm 4.64, \mathrm{t}=3.082$, $\mathrm{p}=0.005$; T2: $13.05 \pm 8.31$ vs. $5.81 \pm$ 4.46, $\mathrm{t}=2.823, \mathrm{p}=0.017)$. Leukocytes count (T1: $10.63 \pm 7.5$ vs. $6.98 \pm 2.98$, $\mathrm{t}=-2.125, \mathrm{p}=0.046$; T2: $14.71 \pm 6.33$ vs. $9.52 \pm 4.03, \mathrm{t}=-3.743, \mathrm{p}<0.001)$ and CRP (T1: $129.27 \pm 111.21$ vs. $78.73 \pm 67.54$, $\mathrm{t}=-2.529, \quad \mathrm{p}=0.013 ; \mathrm{T} 2: 89.4 \pm 76.97$ vs. $12.74 \pm 28.82, t=-3.407, p=0.005$ ) were also significantly higher in patients with lethal outcome at both times. Age, gender, as well as relative counts (i.e., their percentages) of neutrophils and lymphocytes did not show significant associations with patient outcome.

Table 1. Bivariate analysis of associations between patient outcome and other variables of interest.

\begin{tabular}{|c|c|c|c|}
\hline & $\begin{array}{l}\text { Alive } \\
(\mathrm{N}=74)\end{array}$ & $\begin{array}{l}\text { Dead } \\
(\mathrm{N}=21)\end{array}$ & $\begin{array}{l}\text { Statistic, } \\
p \text { value }\end{array}$ \\
\hline Age (years) (mean \pm SD) & $60.59 \pm 13.75$ & $66.95 \pm 13.9$ & $\begin{array}{l}t=-1.866 \\
p=0.065\end{array}$ \\
\hline $\begin{array}{l}\text { Gender - } \mathrm{n}(\%) \\
\text { Male }(\mathrm{n}=56) \\
\text { Female }(\mathrm{n}=39)\end{array}$ & $\begin{array}{l}41(73.2) \\
33(84.6)\end{array}$ & $\begin{array}{l}15(26.8) \\
6(15.4)\end{array}$ & $\begin{array}{r}x 2=1.735 \\
p=0.188\end{array}$ \\
\hline Length of hospital stay (days) (mean \pm SD) & $9.68 \pm 4.72$ & $5.33 \pm 5.06$ & $\begin{array}{l}t=3.662 \\
p=0.001\end{array}$ \\
\hline $\begin{array}{l}\text { Neutrophils T1 (\%) } \\
(\text { mean } \pm \text { SD) }\end{array}$ & $76.45 \pm 11.46$ & $75.11 \pm 28.31$ & $\begin{array}{l}\mathrm{t}=0.201 \\
\mathrm{p}=0.843\end{array}$ \\
\hline $\begin{array}{l}\text { Neutrophils T2 (\%) } \\
(\text { mean } \pm \text { SD) }\end{array}$ & $73.44 \pm 13.82$ & $79.17 \pm 27.12$ & $\begin{array}{l}t=-1.087 \\
p=0.28\end{array}$ \\
\hline $\begin{array}{l}\text { Lymphocytes T1 (\%) } \\
\text { (mean } \pm \text { SD) }\end{array}$ & $17.06 \pm 9.65$ & $12.97 \pm 19.27$ & $\begin{array}{l}t=1.291 \\
p=0.2\end{array}$ \\
\hline $\begin{array}{l}\text { Lymphocytes T2 (\%) } \\
(\text { mean } \pm \text { SD) }\end{array}$ & $19.29 \pm 11.12$ & $15.65 \pm 26.11$ & $\begin{array}{l}\mathrm{t}=0.798 \\
\mathrm{p}=0.427\end{array}$ \\
\hline $\begin{array}{l}\text { Neutrophils/Lymphocytes Ratio T1 } \\
\text { (mean } \pm \text { SD) }\end{array}$ & $6.47 \pm 4.64$ & $12.05 \pm 7.53$ & $\begin{array}{l}t=-3.082 \\
p=0.005\end{array}$ \\
\hline $\begin{array}{l}\text { Neutrophils/Lymphocytes Ratio T2 } \\
(\text { mean } \pm \text { SD) }\end{array}$ & $5.81 \pm 4.46$ & $13.05 \pm 8.31$ & $\begin{array}{l}\mathrm{t}=-2.823 \\
\mathrm{p}=0.017\end{array}$ \\
\hline $\begin{array}{l}\text { Leucocytes T1 }\left(\times 10^{9} / \mathrm{L}\right) \\
(\text { mean } \pm \mathrm{SD})\end{array}$ & $6.98 \pm 2.98$ & $10.63 \pm 7.5$ & $\begin{array}{l}\mathrm{t}=-2.125 \\
\mathrm{p}=0.046\end{array}$ \\
\hline $\begin{array}{l}\text { Leucocytes T2 }\left(\times 10^{9} / \mathrm{L}\right) \\
(\text { mean } \pm \mathrm{SD})\end{array}$ & $9.52 \pm 4.03$ & $14.71 \pm 6.33$ & $\begin{array}{l}t=-3.743 \\
p<0.001\end{array}$ \\
\hline $\begin{array}{l}\mathrm{CRP} \text { T1 }(\mathrm{mg} / \mathrm{L}) \\
(\mathrm{mean} \pm \mathrm{SD})\end{array}$ & $78.73 \pm 67.54$ & $129.27 \pm 111.21$ & $\begin{array}{l}t=-2.529 \\
p=0.013\end{array}$ \\
\hline $\begin{array}{l}\mathrm{CRP} T 2(\mathrm{mg} / \mathrm{L}) \\
(\text { mean } \pm \mathrm{SD})\end{array}$ & $12.74 \pm 28.82$ & $89.4 \pm 76.97$ & $\begin{array}{l}\mathrm{t}=-3.407 \\
\mathrm{p}=0.005\end{array}$ \\
\hline
\end{tabular}

${ }^{\star}$ T1 - values at hospitalization; T2 - values at discharge (or the last analysis before death) 
Table 2. Logistic regression model for lethal outcome that includes the factor neutrophils/ lymphocytes ratio in hospitalized patients with COVID-19.

\begin{tabular}{|c|c|c|c|c|c|}
\hline $\begin{array}{l}\text { Dependent } \\
\text { variable }\end{array}$ & Covariates & $\begin{array}{l}\mathrm{B} \\
(\mathrm{SE})\end{array}$ & $\begin{array}{c}\exp ^{b} \\
(95 \% \mathrm{CI})\end{array}$ & $\begin{array}{l}\text { Cox \& Snell } R^{2} ; \\
\text { Nagelkerke } R^{2}\end{array}$ & $\begin{array}{l}\chi^{2} \text { of the } \\
\text { Model }(p)\end{array}$ \\
\hline \multirow[t]{10}{*}{ Lethal outcome } & Constant & $\begin{array}{l}17.38 \\
(24.31)\end{array}$ & & \multirow[t]{10}{*}{$\begin{array}{l}.343 ; \\
.617\end{array}$} & \multirow[t]{10}{*}{$\begin{array}{c}32.81 \\
(<0.001)\end{array}$} \\
\hline & Age & $\begin{array}{l}0.03 \\
(0.04)\end{array}$ & $\begin{array}{c}1.03 \\
(0.96-1.11)\end{array}$ & & \\
\hline & Gender & $\begin{array}{l}-0.67 \\
(1.52)\end{array}$ & $\begin{array}{c}0.51 \\
(0.03-10.03)\end{array}$ & & \\
\hline & $\begin{array}{l}\text { Length of hos- } \\
\text { pital stay }\end{array}$ & $\begin{array}{l}-0.37 \\
(0.16)\end{array}$ & $\begin{array}{c}0.69^{*} \\
(0.51-0.96)\end{array}$ & & \\
\hline & Neutrophils T1 & $\begin{array}{c}0.02 \\
(0.18)\end{array}$ & $\begin{array}{c}1.02 \\
(0.71-1.46)\end{array}$ & & \\
\hline & Neutrophils T2 & $\begin{array}{l}-0.29 \\
(0.22)\end{array}$ & $\begin{array}{c}0.75 \\
(0.49-1.15)\end{array}$ & & \\
\hline & $\begin{array}{c}\text { Lymphocytes } \\
\text { T1 }\end{array}$ & $\begin{array}{c}0.23 \\
(0.23)\end{array}$ & $\begin{array}{c}1.26 \\
(0.8-1.98)\end{array}$ & & \\
\hline & $\begin{array}{c}\text { Lymphocytes } \\
\text { T2 }\end{array}$ & $\begin{array}{l}-0.37 \\
(0.29)\end{array}$ & $\begin{array}{c}0.69 \\
(0.39-1.22)\end{array}$ & & \\
\hline & $\begin{array}{l}\text { Neu/Lymph } \\
\text { Ratio T1 }\end{array}$ & $\begin{array}{l}0.34 \\
(0.16)\end{array}$ & $\begin{array}{c}1.404^{\star} \\
(1.03-1.92)\end{array}$ & & \\
\hline & $\begin{array}{l}\text { Neu/Lymph } \\
\text { Ratio T2 }\end{array}$ & $\begin{array}{c}0.31 \\
(0.16)\end{array}$ & $\begin{array}{c}1.36^{\star} \\
(1.001-1.85)\end{array}$ & & \\
\hline
\end{tabular}

Neu/Lymph Ratio - Neutrophils/Lymphocytes Ratio ${ }^{*} \mathrm{p}<0.05$

Table 2 shows that the increase on the Neutrophils/lymphocytes ratio scale both at hospitalization and at discharge (or the last analysis before death) leads to increase in the odds of lethal outcome (T1: $100 *[1.404-1]=$ 40.4\% increased odds; T2: 100*[1.36-1] $=36 \%$ increased odds). The increase on the Length of hospital stay scale leads to decrease in the odds of lethal outcome $(100 *[0.69-1]=-31 \%$ decreased odds).

Table 3 shows the logistic regression model for lethal outcome that includes the factor leukocytes count in hospitalized patients with COVID-19. 
Table 3. Logistic regression model for lethal outcome that includes the factor leukocytes count in hospitalized patients with COVID-19

\title{
Dependent
} variable

\author{
Covariates
}

$\begin{array}{cccc}\text { B } & \exp ^{b} & \text { Cox \& Snell } R^{2} ; & \chi^{2} \text { of the } \\ (\mathrm{SE}) & (95 \% \mathrm{CI}) & \text { NagelkerkeR }^{2} & \operatorname{Model}(p)\end{array}$

\begin{tabular}{|c|c|c|c|c|c|}
\hline & Constant & $\begin{array}{c}-2.16 \\
(23.54)\end{array}$ & & & \\
\hline & Age & $\begin{array}{c}0.04 \\
(0.04)\end{array}$ & $\begin{array}{c}1.04 \\
(0.96-1.13)\end{array}$ & & \\
\hline & Gender & $\begin{array}{l}-0.44 \\
(1.66)\end{array}$ & $\begin{array}{c}0.64 \\
(0.03-16.48)\end{array}$ & & \\
\hline & $\begin{array}{l}\text { Length of hospi- } \\
\text { tal stay }\end{array}$ & $\begin{array}{l}-0.32 \\
(0.13)\end{array}$ & $\begin{array}{c}0.73^{\star} \\
(0.56-0.94)\end{array}$ & & \\
\hline & Neutrophils T1 & $\begin{array}{c}0.14 \\
(0.17)\end{array}$ & $\begin{array}{c}1.15 \\
(0.83-1.59)\end{array}$ & & \\
\hline $\begin{array}{l}\text { Lethal out- } \\
\text { come }\end{array}$ & Neutrophils T2 & $\begin{array}{l}-0.17 \\
(0.22)\end{array}$ & $\begin{array}{c}0.85 \\
(0.55-1.3)\end{array}$ & $\begin{array}{l}.296 ; \\
.532\end{array}$ & $\begin{array}{c}27.38 \\
(0.001)\end{array}$ \\
\hline & Lymphocytes T1 & $\begin{array}{l}0.17 \\
(0.2)\end{array}$ & $\begin{array}{c}1.18 \\
(0.8-1.74)\end{array}$ & & \\
\hline & Lymphocytes T2 & $\begin{array}{l}-0.31 \\
(0.28)\end{array}$ & $\begin{array}{c}0.73 \\
(0.42-1.27)\end{array}$ & & \\
\hline & Leukocytes T1 & $\begin{array}{c}0.34 \\
(0.15)\end{array}$ & $\begin{array}{c}1.403^{*} \\
(1.04-1.89)\end{array}$ & & \\
\hline & Leukocytes T2 & $\begin{array}{c}0.22 \\
(0.11)\end{array}$ & $\begin{array}{c}1.24^{\star} \\
(1.001-1.55)\end{array}$ & & \\
\hline
\end{tabular}

Table 3 shows that increase on the Leukocytes count scale both at hospitalization and at discharge (or the last analysis before death) leads to increase in the odds of lethal outcome (T1: $100 *[1.403-1]=40.3 \%$ increased odds; T2: $100 *[1.24-1]=24 \%$ increased odds). The increase on the Length of hospital stay scale leads to decrease in the odds of lethal outcome $(100 *[0.73-1]=-27 \%$ decreased odds).

Table 4 shows the logistic regression model for lethal outcome that includes the factor CRP count in hospitalized patients with COVID-19. 
Table 4. Logistic regression model for lethal outcome that includes the factor CRP in hospitalized patients with COVID-19

\begin{tabular}{|c|c|c|c|c|c|}
\hline $\begin{array}{l}\text { Dependent } \\
\text { variable }\end{array}$ & Covariates & $\begin{array}{c}\text { B } \\
(\text { SE) }\end{array}$ & $\begin{array}{c}\exp ^{b} \\
(95 \% \mathrm{CI})\end{array}$ & $\begin{array}{l}\text { Cox \& Snell R; } \\
\text { Nagelkerke } R^{2}\end{array}$ & $\begin{array}{l}\chi^{2} \text { of the } \\
\text { Model }(p)\end{array}$ \\
\hline \multirow{10}{*}{$\begin{array}{l}\text { Lethal out- } \\
\text { come }\end{array}$} & Constant & $\begin{array}{c}-5.36 \\
(20.99)\end{array}$ & & \multirow{10}{*}{$\begin{array}{l}.286 ; \\
.512\end{array}$} & \multirow{10}{*}{$\begin{array}{l}25.99 \\
(0.001)\end{array}$} \\
\hline & Age & $\begin{array}{c}0.04 \\
(0.04)\end{array}$ & $\begin{array}{c}1.04 \\
(0.97-1.11)\end{array}$ & & \\
\hline & Gender & $\begin{array}{l}-0.73 \\
(1.28)\end{array}$ & $\begin{array}{c}0.48 \\
(0.04-5.84)\end{array}$ & & \\
\hline & $\begin{array}{l}\text { Length of hospi- } \\
\text { tal stay }\end{array}$ & $\begin{array}{c}-0.2 \\
(0.12)\end{array}$ & $\begin{array}{c}0.82 \\
(0.64-1.04)\end{array}$ & & \\
\hline & Neutrophils T1 & $\begin{array}{c}0.01 \\
(0.16)\end{array}$ & $\begin{array}{c}1.01 \\
(0.74-1.38)\end{array}$ & & \\
\hline & Neutrophils T2 & $\begin{array}{c}0.01 \\
(0.17)\end{array}$ & $\begin{array}{c}1.01 \\
(0.72-1.4)\end{array}$ & & \\
\hline & Lymphocytes T1 & $\begin{array}{l}0.06 \\
(0.19)\end{array}$ & $\begin{array}{c}1.07 \\
(0.73-1.56)\end{array}$ & & \\
\hline & Lymphocytes T2 & $\begin{array}{l}-0.03 \\
(0.21)\end{array}$ & $\begin{array}{c}0.97 \\
(0.64-1.46)\end{array}$ & & \\
\hline & CRP T1 & $\begin{array}{c}0.01 \\
(0.01)\end{array}$ & $\begin{array}{c}1.01^{*} \\
(1.001-1.02)\end{array}$ & & \\
\hline & CRP T2 & $\begin{array}{c}0.02 \\
(0.01)\end{array}$ & $\begin{array}{c}1.02^{\star} \\
(1.002-1.04)\end{array}$ & & \\
\hline
\end{tabular}

Table 4 shows that increase on the CRP scale both at hospitalization and at discharge (or the last analysis before death) leads to slight increase in the odds of lethal outcome (T1: $100 *[1.01-1]=1 \%$ increased odds; $\mathrm{T} 2$ : $100 *[1.02-1]=2 \%$ increased odds).

\section{Discussion}

Continuous monitoring of relevant laboratory and clinical parameters will assist in the detection of those patients who are at risk of developing severe COVID-19. With the help of these parameters, appropriate therapy will be started at time, which can change the course of this disease. A routine blood tests are possible in almost every medical laboratory and hospital. Some blood count parameters, such as NEU or LY, may indicate good distinction between patients who will develop mild and those who will develop severe clinical picture with COVID-19. Previous studies have shown16,17 that the ratio between NEU and LY, known as NLR, provides even more accurate results on the severity of the clinical picture that may develop in patients with viral infections. These 
studies also saw the importance of NLR as a parameter that can predict the course of the disease. According to them, the value of 5 was a limit reference value, and $80 \%$ of patients who had a value above or below this corresponded to the type of the clinical picture they later developed during hospitalization. During the past year, many studies have emphasized the values of CRP, PCT, FIB, LDH and D-D as acute-phase reaction proteins that are closely related to the progression of COVID-19.18,19

Similar to previous studies ${ }^{20-23}$, our study has shown the importance of NLR as a parameter in monitoring the course of the disease in patients with COVID-19. The study also showed the association of this parameter with other pivotal laboratory parameters used to diagnose this disease. This result further suggests that the NLR can be used as a parameter to assess the severity of a patient developing a severe clinical picture, which may be explained by the increased number of Neu and the decreased Ly in patients with severe COVID-19, as a consequence of complex immune responses in the body. ${ }^{24}$

The conclusions reached so far related to this issue say that patients with severe COVID-19 have dysregulation in the immune response that leads to the development of a hyperinflammatory response to the virus.21 As it is well known, elevated NLR values in peripheral blood are commonly associated with a systemic inflammatory response. The increased value so far has been prognostic for many diseases such as: cardiovascular, autoimmune infectious and malignant diseases. ${ }^{26,27}$ Therefore, determining the laboratory parameters that suggest this hyper-inflammatory response of the organism are of crucial importance in the monitoring of patients to reduce mortality from this disease. Such biomarkers that may indicate a hyper-inflammatory response from the body, as mentioned earlier, and are available in all laboratories are the ratio between neutrophils and lymphocytes (NLR), as well as the ratio between lymphocytes and C-reactive protein (LCR). In the study, a meta-analysis was performed to assess the possibility of NLR and LCR to serve as predictors of the severity of the clinical picture that would develop in patients.

Meta-analysis was performed, calculating the standardized mean difference (SMD) and the 95\% confidence interval (95\% CI) of the NLR and LCR values in patients with COVID-19 with or without severe disease. All studies included in this meta-analysis were conducted in China. A total of 825 patients were included, of whom 407 (49.15\%) had a severe clinical picture, and the sample size from study to study varied from 48 to 452 patients. The NLR values were found to be significantly increased $(\mathrm{SMD}=2.404,95 \% \mathrm{CI}=0.98-3.82)$ in COVID-19, patients with severe clinical picture, and the LCR value was significantly reduced $(\mathrm{SMD}=-0.912$, $95 \% \mathrm{CI}=-1.275$ to -0.550$)$, compared to COVID-patients with mild clinical picture. Although there are studies showing that COVID-19 patients have an increase in neutrophil and C-reactive protein and a decrease in lymphocyte counts, few studies have considered effective NLR and LCR markers as predictors of complications of COVID19.21, 27-31 From all this, it can be concluded that the increased value of NLR and the decreased LCR in patients with COVID-19 lead to an enhanced inflammatory response, 
which indicates a poor prognosis.

The ratio between neutrophils and lymphocytes (NLR), alone, but also in combination with other parameters, has been shown to determine a patient's risk of whether it is a mild / moderate or severe clinical case. Also, its increased value is associated with higher COVID-19 mortality. ${ }^{15}$, 32-37

However, still little is known about its value as a predictor of the patient's clinical picture as well as the outcome of the disease. Determining NLR when a patient is admitted to hospital has a high value in predicting deteriorating health, shock, or death, with areas under the curve of $0.801,0.830$, and 0.828 , respectively, and a cutoff value of 2.6937. The sensitivity of the $\geq 2.6937$ NLR cutoff for predicting the subsequent presence of disease deterioration, shock and death was $82.0 \%$, 93.3\%, and 92.9\%, respectively, and the corresponding negative predictive values were 95.7\%, 99.5\% and 99.5\%, respectively. Compared with patients who had an NLR of < 2.6937, the adjusted hazard ratios for disease deterioration, shock and death were 4.1, 13.1 and 11.3, respectively, among those with an NLR of $\geq 2.6937$. The cumulative risk of the clinical outcome was significantly higher in patients with an NLR of $\geq 2.6937$ than in those with an NLR of < 2.6937. Early detection of patients who are at risk of developing a severe clinical condition can help in providing appropriate care, as well as appropriate management of resources that are quite limited during a pandemic. ${ }^{38}$

For patients with COVID-19 the elevated NLR values are due to both the damage that occurs in the lung parenchyma and the prominent de- rangement of the lymph hematopoietic system. Elevated NLR levels may indicate the severity of the condition in COVID-19 patients as well as the patient's immune status. Recently, several studies have shown the importance of elevated levels of this marker in assessing the severity of the clinical picture in patients with COVID-19 as well as the possibility of a fatal outcome..$^{15,25,32-38}$ The NLR was also included as a variable in a clinical risk score to predict the occurrence of critical illness in hospitalized patients with COVID-19.38 This finding can be extremely helpful in the accurate and precise triage of patients on admission to a hospital where COVID-19 patients are treated, especially in areas where there are many patients and limited medical resources.

Different studies have so far reported different NLR thresholds. Therefore, in practice, it is not precise which threshold should be considered when categorizing the severity of the clinical picture that a patient may develop. The study demonstrated not only the ability of this biomarker to predict the severity of the clinical condition that may develop in a patient with COVID-19, but also the likelihood of a fatal outcome. In laboratory examination of peripheral blood in COVID-19patients, it has been noted that the absolute value of white blood cells is normal or slightly reduced, but lymphopenia has been expressed. ${ }^{39}$ Also, in patients with severe clinical condition or patients with fatal outcome, a rapid decrease in the number of lymphocytes and a gradual increase in the number of neutrophils has been observed. This is probably due to the highly pronounced inflammatory response on one hand, and the immune sup- 
pression by SARSCoV-2 on the other. Specifically, neutrophils, as proinflammatory cells with pronounced antimicrobial potential, are activated by proinflammatory mediators associated with viral infection, such as interleukin-6 and interleukin-8.40 At the same time SARSCoV-2 exerts immune suppression, leading to a reduction in $\mathrm{CD} 3+\mathrm{T}$ cells, CD4 $+\mathrm{T}$ cells and CD8 + T cells. ${ }^{41,42}$

Having in mind these observations, NLR is an important marker that may be associated with progression of the clinical picture in patients with COVID-19 and can be relatively easily determined by routine peripheral blood laboratory tests. To date, four meta-analyses have indicated that this marker is elevated in patients with a severe clinical picture compared to those with mild, but none of them assessed the predictive value of NLR for the severity and mortality of COVID-19. ${ }^{43-46}$

Recent meta-analysis has shown that lymphopenia is a good biomarker indicating an increased risk of severe COVID-19 infection. ${ }^{47}$ Regarding our results, a higher lymphopenia level was found in the severe cases, but the assessment of the prognosis value of the biological parameters in correlation with the severity of the disease demonstrated that CRP level was more relevant. C-reactive protein has been shown to be a good biomarker for predicting poor outcome in patients with COVID-19.These results were in line with the results obtained in a study conducted in Wuhan by Luo et al. In the study, the sensitivity was $65 \%$ and the specificity $83.7 \%$, with a positive predictive value (PPV) of $81.6 \%$ and a negative predictive value (NPV) of $68.2 \% .48$ The findings have been consistent with recent publications stating that the value of CRP on admission is a sensitive and early indicator for COVID19 severity. ${ }^{48-50}$ Studies have also shown that the level of C-reactive protein correlates with the extent of the lesion in the lung on a tomographic scan..$^{51}$ At the time of admission, detailed laboratory tests are sometimes difficult to perform, but determining CRP is a routine procedure that can predict the severity of the clinical picture that would develop in a patient with COVID-19.

\section{Conclusion}

Analyzing the obtained laboratory parameters in patients in our study as well as in several other studies, showed that CRP and NLR are two laboratory parameters that can be used as markers to predict the severity of the clinical manifestationin COVID-19patients, certainly complemented by other pivotal laboratory indicators. The most important part in the managing of COVID-19 is early and accurate diagnosis, identification of severe patients and active and timely treatment as soon as possible.

\section{References}

1. Wang W, Lin XD, Guo WP, Zhou RH, Wang MRet al. Discovery, diversity and evolution of novel coronaviruses sampled from rodents in China. Virology 2015 Jan 1;474:1927. doi: 10.1016/j.virol.2014.10.017

2. Elezkurtaj S, Greuel S, Ihlow J, Michaelis EG, Bischoff P, et al. Causes of death and comorbidities in hospitalized patients with COVID-19. Sci Rep 2021 Feb 19;11(1):4263. doi: 10.1038/s41598-021-82862-5

3. Tian W, Jiang W, Yao J, Nicholson 
CJ, Li RH et al. Predictors of mortality in hospitalized COVID-19 patients: A systematic review and meta-analysis. J Med Virol 2020 Oct;92(10):1875-1883. doi: 10.1002/ jmv.26050

4. Lagunas-Rangel FA. Neutrophil-to-lymphocyte ratio and lymphocyte-to-C-reactive protein ratio in patients with severe coronavirus disease 2019 (COVID-19): A meta analysis. J Med Virol 2020; 92(10):1733-1734

5. Hurlimann J, Thorbecke GJ, Hochwald GM. The liver as the site of C-reactive protein formation. J Exp Med 1966;123(2):365-78. doi: 10.1084/jem.123.2.365.

6. Young B, Gleeson M, Cripps AW. C-reactive protein: A critical review. Pathology. 1991;23(2):118-124. doi:10.3109/00313029109060809

7. Pepys MB, Hirschfield GM. C-reactive protein: a critical update. J Clin Invest. 2003;111(12):1805-1812. doi:10.1172/JCI200318921

8. Li YP, Mold C, Du Clos TW. Sublytic complement attack exposes C-reactive protein binding sites on cell membranes. J Immunol 1994; 152(6):2995-3005.

9. Mold C, Baca R, Du Clos TW. Serum amyloid $\mathrm{P}$ component and C-reactive protein opsonize apoptotic cells for phagocytosis through Fcgamma receptors. J Autoimmun 2002; 19(3):147-54. doi: 10.1006/ jaut.2002.0615.

10. Forget P, Khalifa C, Defour JP, Latinne D, Van Pel MC, et al. What is the normal value of the neutrophil-to-lymphocyte ratio?. BMC Res Notes 2017;10(1):12. doi:10.1186/ s13104-016-2335-5
11. Kang $\mathrm{MH}$, Go SI, Song $\mathrm{HN}$ et al. The prognostic impact of the neutrophil-to-lymphocyte ratio in patients with small-cell lung cancer. Br J Cancer 2014;111(3):452-460. Doi: 10.1038/bjc.2014.317.

12. Templeton AJ, McNamara MG, Šeruga B, Vera-Badillo FE, Aneja Pet al. Prognostic role of neutrophil-to-lymphocyte ratio in solid tumors: a systematic review and meta-analysis. J Natl Cancer Inst 2014;106(6):dju124. doi: 10.1093/ jnci/dju124

13. Ayça B, Akın F, Celik O, Sahin I, Yildiz SS et al. Neutrophil to Lymphocyte Ratio is related to stent thrombosis and high mortality in patients with acute myocardial infarction. Angiology 2015; 66(6):54552. doi: 10.1177/0003319714542997

14. Paliogiannis P, Fois AG, Sotgia S, Mangoni AA, Zinellu Eet al. Neutrophil to lymphocyte ratio and clinical outcomes in COPD: recent evidence and future perspectives. Eur Respir Rev 2018;27(147):170113. doi: 10.1183/16000617.0113-2017

15. Fu J, Kong J, Wang W, Wu M, Yao $\mathrm{L}$ et al. The clinical implication of dynamic neutrophil to lymphocyte ratio and D-dimer in COVID-19: A retrospective study in Suzhou China. Thromb Res 2020;192:3-8. doi: 10.1016/j.thromres.2020.05.006

16. Han Q, Wen X, Wang L, Han X, Shen Y et al. Role of hematological parameters in the diagnosis of influenza virus infection in patients with respiratory tract infection symptoms. J Clin Lab Anal 2020; 34(5):e23191. doi: 10.1002/jcla.23191

17. Liu YP, Li GM, He J, Liu Y, Li M et al. Combined use of the neutrophil-to-lymphocyte ratio and CRP 
to predict 7-day disease severity in 84 hospitalized patients with COVID-19 pneumonia: a retrospective cohort study. Ann Transl Med 2020;8(10):635. doi: 10.21037/atm20-2372

18. Ghahramani S, Tabrizi R, Lankarani KB, Kashani SMA, Rezaei Set al. Laboratory features of severe vs. non-severe COVID-19 patients in Asian populations: a systematic review and meta-analysis. Eur J Med Res 2020;25(1):30. doi: 10.1186/ s40001-020-00432-3

19. Bao J, Li C, Zhang K, Kang H, Chen $\mathrm{W}$ et al. Comparative analysis of laboratory indexes of severe and non-severe patients infected with COVID-19. Clin Chim Acta 2020; 509:180-194. doi: 10.1016/j. сcа.2020.06.009

20. Sun S, Cai X, Wang H, He G, Lin Yet al. Abnormalities of peripheral blood system in patients with COVID-19 in Wenzhou, China. Clin Chim Acta 2020; 507:174-180. doi: 10.1016/j.cca.2020.04.024

21. Qin C, Zhou L, Hu Z, Zhang S, Yang $S$ et al. Dysregulation of immune response in patients with coronavirus 2019 (COVID-19) in Wuhan, China. Clin Infect Dis 2020; 71(15):762768. doi: 10.1093/cid/ciaa248

22. Kong $\mathrm{M}$, Zhang $\mathrm{H}$, Cao $\mathrm{X}$, Mao $\mathrm{X}, \mathrm{Lu}$ Z. Higher level of neutrophil-to-lymphocyte is associated with severe COVID-19. Epidemiol Infect 2020;148:e139. doi: 10.1017/ S0950268820001557

23. Yang AP, Liu JP, Tao WQ, Li HM. The diagnostic and predictive role of NLR, d-NLR and PLR in COVID-19 patients. Int Immunopharmacol
2020;84:106504. doi: 10.1016/j.intimp.2020.106504

24. Liu X, Zhang R, He G. Hematological findings in coronavirus disease 2019: indications of progression of disease. Ann Hematol 2020; 99(7):1421-1428. doi: 10.1007/s00277020-04103-5

25. Huguet E, Maccallini G, Pardini P, Hidalgo M, Obregon Set al. Reference values for Neutrophil to Lymphocyte Ratio (NLR), a biomarker of cardiovascular risk, according to age and sex in a Latin American Population. Curr Probl Cardiol 2021; 46(3):100422. doi: 10.1016/j. cpcardiol.2019.04.002

26. Russell CD, Parajuli A, Gale HJ, Bulteel NS, Schuetz Pet al. The utility of peripheral blood leucocyte ratios as biomarkers in infectious diseases: A systematic review and meta-analysis. J Infect 2019;78(5):339-348. doi: 10.1016/j. jinf.2019.02.006

27. Huang C, Wang Y, Li X, Ren L, Zhao J et al. Clinical features of patients infected with 2019 novel coronavirus in Wuhan, China. Lancet. 2020; 395(10223):497-506. doi: 10.1016/ S0140-6736(20)30183-5

28. Wang Z, Yang B, Li Q, Wen L, Zhang R. Clinical features of 69 cases with coronavirus disease 2019 in Wuhan, China. Clin Infect Dis 2020;71(15):769-777. doi: 10.1093/ cid/ciaa272

29. Zhang JJ, Dong X, Cao YY, Yuan YD, Yang YBet al. Clinical characteristics of 140 patients infected with SARS-CoV-2 in Wuhan, China. Allergy 2020; 75(7):1730-1741. doi: 10.1111/all.14238

30. Gao Y, Li T, Han M, Li X, Wu D et 
al. Diagnostic utility of clinical laboratory data determinations for patients with the severe COVID-19. J Med Virol 2020; 92(7):791-796. doi: 10.1002/jmv.25770

31. Li K, Wu J, Wu F, Guo D, Chen L et al. The clinical and chest ct features associated with severe and critical COVID-19 pneumonia. Invest Radiol 2020 Jun;55(6):327-331.

32. Wang C, Deng R, Gou L, Fu Z, Zhang Xet al. Preliminary study to identify severe from moderate cases of COVID-19 using combined hematology parameters. Ann Transl Med 2020; 8(9):593. doi: 10.21037/atm20-3391

33. Shang W, Dong J, Ren Y, Tian M, Li Wat al. The value of clinical parameters in predicting the severity of COVID-19. J Med Virol 2020; 92(10):2188-2192. doi: 10.1002/ jmv.26031

34. Yang AP, Liu JP, Tao WQ, Li HM. The diagnostic and predictive role of NLR, d-NLR and PLR in COVID-19 patients. Int Immunopharmacol. 2020; 84:106504. doi: 10.1016/j.intimp.2020.106504

35. Liu Y, Du X, Chen J, Jin Y, Peng L et al. Neutrophil-to-lymphocyte ratio as an independent risk factor for mortality in hospitalized patients with COVID-19. J Infect 2020; 81(1):e6-e12. doi: 10.1016/j. jinf.2020.04.002

36. Yan X, Li F, Wang X, Yan J, Zhu F et al. Neutrophil to lymphocyte ratio as prognostic and predictive factor in patients with coronavirus disease 2019: A retrospective cross-sectional study. J Med Virol 2020;92(11):2573-2581. doi: 10.1002/ jmv.26061
37. Tatum D, Taghavi S, Houghton A, Stover J, Toraih E et al. Neutrophil-to-Lymphocyte Ratio and outcomes in Louisiana COVID-19 patients. Shock 2020; 54(5):652-658. doi: 10.1097/ SHK.0000000000001585

38. Liang W, Liang $\mathrm{H}, \mathrm{Ou} \mathrm{L}$, Chen B, Chen A et al. China Medical Treatment Expert Group for COVID-19. Development and validation of a clinical risk score to predict the occurrence of critical illness in hospitalized patients with COVID-19. JAMA Intern Med 2020;180(8):10811089. doi: 10.1001/jamainternmed.2020.2033

39. Singhal T. A Review of Coronavirus Disease-2019 (COVID-19). Indian J Pediatr 2020; 87(4):281-286. doi: 10.1007/s12098-020-03263-6

40. Mangalmurti N, Hunter CA. Cytokine Storms: Understanding COVID-19. Immunity 2020; 53(1):19-25. doi: 10.1016/j.immuni.2020.06.017

41. Azkur AK, Akdis M, Azkur D, Sokolowska M, van de Veen Wet al. Immune response to SARS-CoV-2 and mechanisms of immunopathological changes in COVID-19. Allergy 2020; 75(7):1564-1581. doi: 10.1111/ all.14364

42. Zhang X, Tan Y, Ling Y, Lu G, Liu F, Yi Z et al. Viral and host factors related to the clinical outcome of COVID-19. Nature 2020;583(7816):437-440. doi: 10.1038/s41586-020-2355-0

43. Chan AS, Rout A. Use of Neutrophil-to-Lymphocyte and Platelet-to-Lymphocyte Ratios in COVID-19. J Clin Med Res 2020;12(7):448-453. doi: 10.14740/ jocmr 4240 
44. Zeng F, Li L, Zeng J, Deng Y, Huang $\mathrm{H}$ et al. Can we predict the severity of coronavirus disease 2019 with a routine blood test? Pol Arch Intern Med 2020;130(5):400-406. doi: 10.20452/pamw.15331

45. Ghahramani S, Tabrizi R, Lankarani KB, Kashani SMA, Rezaei Set al. Laboratory features of severe vs. non-severe COVID-19 patients in Asian populations: a systematic review and meta-analysis. Eur J Med Res 2020;25(1):30. doi: 10.1186/ s40001-020-00432-3

46. Lagunas-Rangel FA. Neutrophil-to-lymphocyte ratio and lymphocyte-to-C-reactive protein ratio in patients with severe coronavirus disease 2019 (COVID-19): A meta-analysis. J Med Virol 2020;92(10):1733-1734. doi: 10.1002/ jmv.25819

47. Zhao Q, Meng M, Kumar R, Wu Y, Huang Jet al. Lymphopenia is associated with severe coronavirus disease 2019 (COVID-19) infections: A systemic review and meta-analysis. Int J Infect Dis 2020;96:131-135. doi: 10.1016/j.ijid.2020.04.086

48. Luo X, Zhou W, Yan X, Guo T, Wang Bet al. Prognostic Value of C-Reactive Protein in Patients With Coronavirus 2019. Clin Infect Dis 2020;71(16):2174-2179. doi: 10.1093/ cid/ciaa641

49. Chen W, Zheng KI, Liu S, Yan Z, Xu C et al. Plasma CRP level is positively associated with the severity of COVID-19. Ann Clin Microbiol Antimicrob 2020;19(1):18. doi: 10.1186/ s12941-020-00362-2

50. Wang G, Wu C, Zhang Q, Wu F, Yu $B$ et al. C-Reactive Protein level may predict the risk of COVID-19 aggravation. Open Forum Infect
Dis 2020;7(5):ofaa153. doi: 10.1093/ ofid/ofaa153

51. Tan C, Huang Y, Shi F, Tan K, Ma Q et al. C-reactive protein correlates with computed tomographic findings and predicts severe COVID-19 early. J Med Virol 2020;92(7):856862. doi: 10.1002/jmv.25871 